British \& Irish Botany 1(2): 70-90, 2019

\title{
Changing status of Blysmus compressus (Flat Sedge) in the Sefton Coast sand-dunes, north Merseyside, UK
}

\author{
Philip H. Smith* \\ 9 Hayward Court, Watchyard Lane, Formby, Liverpool, UK, L37 3QP \\ *Corresponding author: Philip H. Smith, email: philsmith1941@tiscali.co.uk \\ This pdf constitutes the Version of Record published on $21^{\text {st }}$ May 2019

\begin{abstract}
A 2018 survey of the nationally 'Vulnerable' Blysmus compressus (Flat-sedge) in the Sefton Coast sand-dunes, north Merseyside (v.c.59, South Lancashire), aimed to update information collected on distribution and habitats a decade earlier. As in 2008, the plant was mainly found in calcareous dune-slacks of recent origin, with short, open, speciesrich vegetation on gley soils with a relatively high $\mathrm{pH}$. Sites with a lower sward height supported a higher percentage cover of $B$. compressus. The largest populations were associated with sites that had been disturbed by recreational trampling, occasional vehicle use and/or grazing, especially by rabbits. Twenty-two sites were recorded, seven being new. Overall, the area occupied by B. compressus declined by $17 \%$, two 2008 sites being lost. Similarly, an estimate of $15-20,000$ plants in the earlier survey fell to 12,600 . Losses were attributed to vegetation overgrowth and scrub development, partly resulting from lower rabbit numbers and reduced management input. The plant occurred in a range of vegetation types but matches to known UK National Vegetation Classification communities were generally poor. Management methods to conserve $B$. compressus and other vulnerable taxa are discussed.
\end{abstract}

\section{Key words}

Declining species; dune management; dune-slacks; grazing; rabbits; vegetation overgrowth.

\section{Introduction}

Blysmus compressus (L.) Panz. ex Link (Flat-sedge) (Cyperaceae) (Fig. 1) is a rhizomatous perennial of open vegetation in marshes and fens and in short, sedge-rich, damp grassland, calcareous flushes, dune-slacks, road verges and stream borders that are subject to flooding, especially on base-rich soils. It has also occasionally been found in brackish ditches at the head of saltmarshes and as a constituent of alluvial meadows on stabilised shingle (Graham, 1988; Halliday, 1997; Jermy et al., 2007; Stroh \& Walker, 2015; Walker et al., 2017). Ellenberg's indicator values in Hill et al. (2004) show that this species is a light-loving plant $(L=8)$, associated with constantly moist to wet soils $(F=8)$ that are base-rich $(R=8)$ and relatively infertile $(N=3)$ and that the plant is generally absent from saline sites $(S=0)$. 
Blysmus compressus occurs from the temperate zone of Western Europe, north to southern Scandinavia, south to North Africa and east, via Turkey and Lebanon, through southern Siberia, Mongolia, Nepal and the mountains of Central Asia as far as Sichuan in China. This plant has been recorded in most English counties but is now extinct in many, being locally abundant only in the north and west. It is confined to one site in Wales and, in Scotland, is found almost entirely to the south of the Central Belt. The species has not been seen in Ireland.

Due to habitat loss, hydrological change, eutrophication, undergrazing and the spread of competitive species, B. compressus has greatly declined in Britain, having been lost from more than half its pre-1930 hectads by 1962 and, subsequently, from $40 \%$ of its post-1930 hectads. Its change index from 1930 to 1999 was -1.28 (Foley \& Porter, 2002). A further decline was reported during the Botanical Society of Britain and Ireland's Threatened Plants Project (2008-2013), which quantified changes in the distribution of selected populations present after 1970. B. compressus was relocated at $66 \%$ of pre-selected sites, which included the Sefton Coast, north Merseyside. The largest populations, with up to 300,000 individuals, were found in flushed grasslands near to streams and rivers in the uplands of Northern England and Southern Scotland (Walker et al., 2017).

Reflecting its recent declines, $B$. compressus, is Red-listed as Vulnerable in the UK and in both England and Wales. B. compressus is also a Species of Principal Importance for the Purpose of Conserving Biodiversity in England and Wales under Section 41of the Natural Environment and Rural Communities Act 2006 and Section 7 of the Environment (Wales) Act 2016, respectively. The plant is Red-listed in many western European countries, including Belgium, Germany, Norway, Croatia, the Czech Republic, Hungary, Finland and Sweden (Cheffings \& Farrell, 2005; Dines, 2008; Stroh et al., 2014; Walker et al., 2017).

Smith (2009a) reviewed the distribution of B. compressus in Northwest England where it is considered a Species of Conservation Importance (Regional Biodiversity Steering Group, 1999). There are records for 69 tetrads in Cumbria, mostly in vicecounty (v.c.) 69, Westmorland (Halliday, 1997). In West Lancashire (v.c.60), the plant recently occurred in two areas: on the banks of the R. Lune and in dune-slacks at Lytham St. Anne's. It is not clear whether it survives at the first locality but a small patch was still present recently at Lytham (D.P. Earl, personal communication, 2018). In v.c.59 (South Lancashire), B. compressus is largely confined to the Sefton Coast sanddunes, the only other sighting being in 1926 at Nelson, Lancashire, where the plant does not seem to have been recorded since. There are no records for Cheshire (v.c.58). 


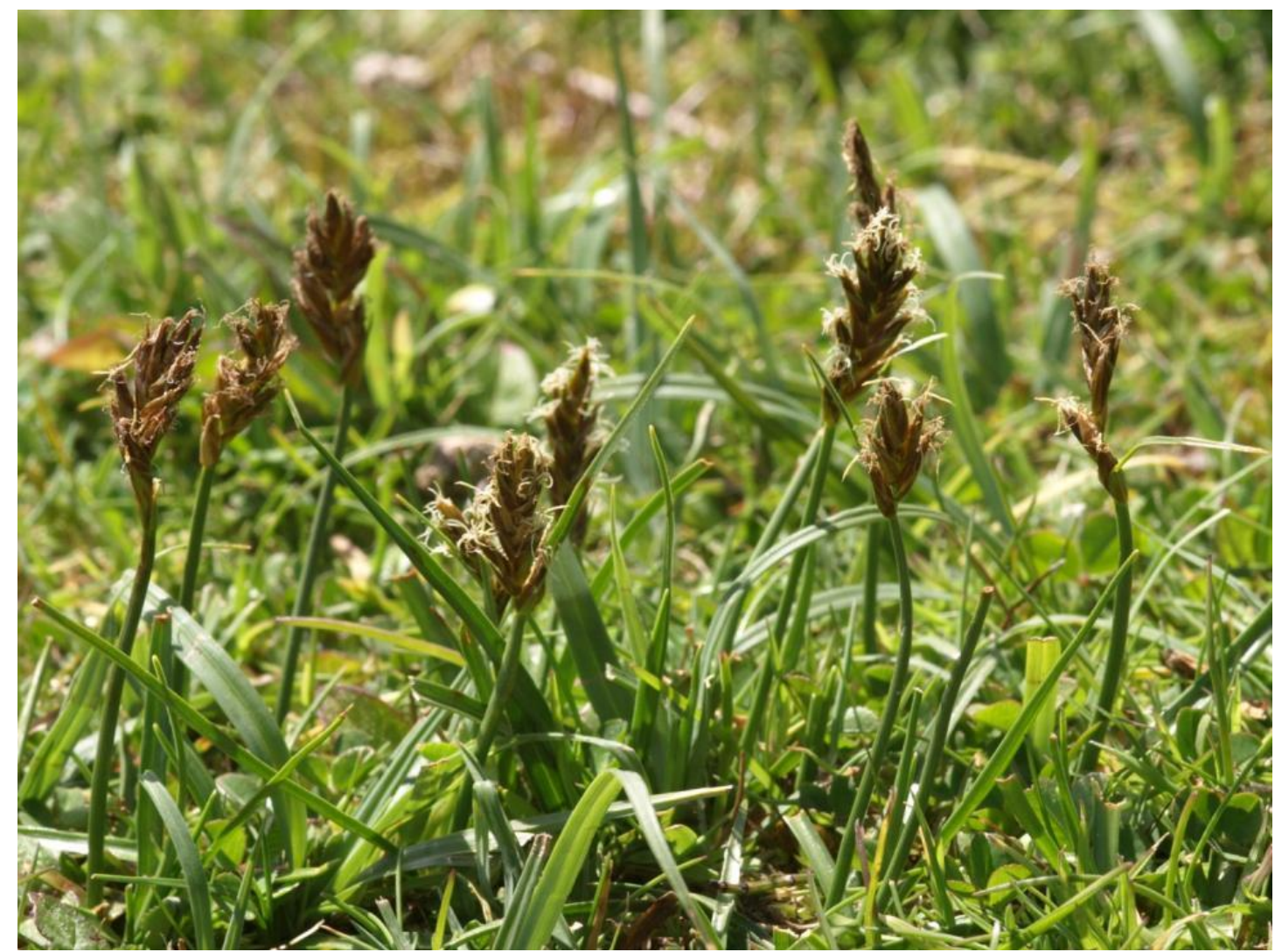

Figure 1. Blysmus compressus in flower at Altcar Training Camp

\section{Status on the Sefton Coast}

Blysmus compressus has been known from the Sefton Coast since 1801, the first quantitative study of its distribution and habitats being in 2008 as part of the BSBI Threatened Plants Project. Smith (2009a) found the species in 18 calcareous dune-slack and damp grassland sites, occupying a total area of over $3000 \mathrm{~m}^{2}$. The estimated total population size was between 15,000 and 20,000 individuals. Most localities were of fairly recent origin and had a history of recreational disturbance and grazing, especially by rabbits (Oryctolagus cuniculus). Analysis of quadrat data gave accordance with UK National Vegetation Classification (NVC) dune-slack communities SD15, SD16 and SD17 and two mesotrophic grassland types (MG8 and MG11) (Rodwell, 1991-2000), though statistical matches were generally poor to very poor.

Since the 2008 study, several new populations of $B$. compressus have been found in the Sefton dunes. There have also been changes in land-ownership and management. Ten years on, therefore, it was considered appropriate to repeat the 2008 survey, the aims being to establish the current status of this nationally declining and vulnerable plant at one of its important English lowland stations, to clarify its habitat characteristics and make conservation recommendations.

\section{Methods}

All known and likely sites for $B$. compressus in the Sefton Coast sand-dune system were visited in June and July 2018. Populations were marked out using bamboo canes, their 
areas being measured by tapes or by pacing and number of plants estimated by counting flower spikes individually or in groups of 5 or 100 , depending on colony size. National Grid References of sites were determined to an accuracy of about $5 \mathrm{~m}$ using a hand-held Garmin Etrex GPS device. For all but the smallest sites, either one or two samples of representative vegetation were recorded in $212 \mathrm{~m} \times 2 \mathrm{~m}$ quadrats using NVC methodology. Reference was made to keys, data tables and community descriptions in Rodwell (1991-2000) to identify vegetation types. Quadrat samples were also analysed using TABLEFIT to determine the degree of fit to known NVC communities and subcommunities (Hill, 2015). Soil type was assessed in each quadrat by visual inspection and a sub-surface soil sample taken, its $\mathrm{pH}$ being measured the same day using a Lutron $\mathrm{PH}-212$ soil pH meter buffered at pH 4 and 7. Notes were also taken on habitat type, condition and current management. Relationships between plant numbers and site area and between vegetation height and percentage cover were analysed using Pearson's correlation coefficient. Vascular plant nomenclature follows Stace (2010) and subsequent updates.

\section{Results}

Twenty-two sites supporting B. compressus were found (Fig. 2), extending from Altcar Training Camp in the south to Queen's Jubilee Nature Trail, Southport in the north, a linear distance of about $12 \mathrm{~km}$. They are situated in six tetrads and three hectads of the UK National Grid. As in 2008, most colonies were in four main areas: Altcar Training Camp (four sites), Cabin Hill National Nature Reserve (three), Birkdale frontal dunes (south) (five) and Birkdale frontal dunes (north) (six). Outlying colonies were also located at the Devil's Hole in Ravenmeols Local Nature Reserve (LNR), Royal Birkdale Golf Course, Birkdale Sandhills LNR and Queen's Jubilee Nature Trail.

A total of over 12,600 plants was counted (Table 1), with a range of 2 to 5000 and a mean of 600 plants per site. The colonies occupied a total area of nearly $2500 \mathrm{~m}^{2}$ (range 1-921 $\mathrm{m}^{2}$; mean $119 \mathrm{~m}^{2}$ ). As might be expected, a positive relationship was found between colony size and area occupied (Fig. 3). A $\log _{10}$ transformation of both axes was used to give a more symmetrical distribution of data.

Seven new sites for the target species were located covering $641 \mathrm{~m}^{2}$ and supporting 3220 plants. B. compressus was not re-found in two of the 2008 sites: a marshy pond edge on Royal Birkdale Golf Course and slack no. 26 Birkdale Sandhills LNR. The former covered $6 \mathrm{~m}^{2}$ and held 10s of plants in the previous survey, while the latter had $100+$ plants within $7 \mathrm{~m}^{2}$. Another site was reported in 2008 by P.S. Gateley (personal communication, 2009) in a slack on the fairway of the $12^{\text {th }}$ hole at Royal Birkdale. However, no plants were found there in 2018. Two sites at Altcar Training Camp's 'I-range' had been mown just before the recording visit and, consequently, only two plants were located in one of them. Previous observations indicated that at least 100 plants were usually present there. While numbers of individuals were only roughly estimated in 2008, site areas were more carefully measured, allowing a direct comparison between the two surveys. Of the sites recorded in both years, nine showed area declines of 23 to $96 \%$ while five increased in size from 7 to $144 \%$ (Table 1). Greatest area losses were in the Birkdale frontal slacks nos. 31, 49 and 50. All three of 
the Cabin Hill sites also showed declines in area, while the largest area gains were in Birkdale frontal slacks 32, 27, 28 and 51/52 (Table 1).

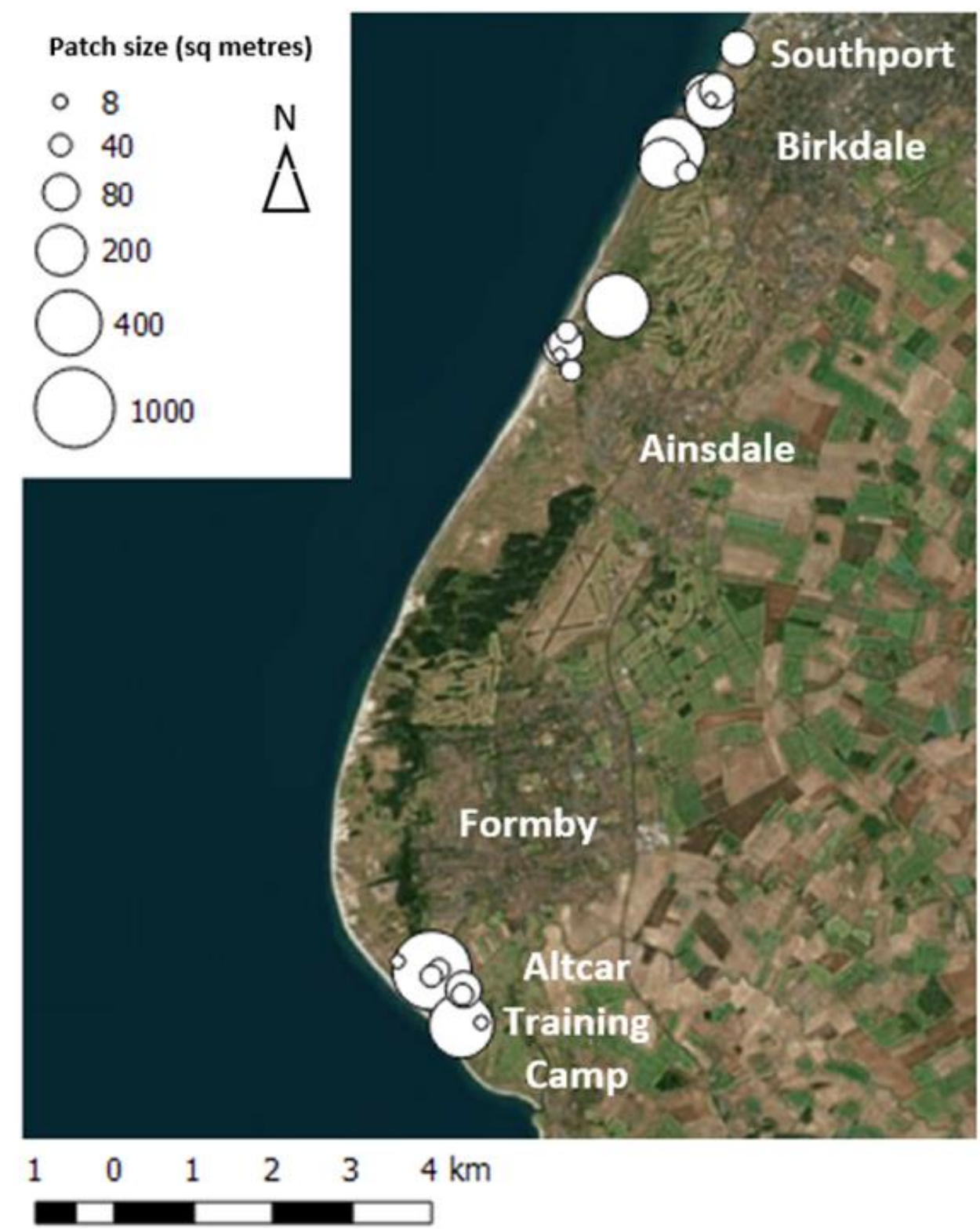

Figure 2. Distribution and area of Blysmus compressus patches on the Sefton Coast 
Table 1. Blysmus compressus sites on the Sefton Coast, 2018 (south to north).

* found after $2008{ }^{1}$ since 2008

\begin{tabular}{|c|c|c|c|c|c|}
\hline Location & $\begin{array}{l}\text { National } \\
\text { Grid Ref. }\end{array}$ & Habitat & $\begin{array}{l}\text { Area } \\
\mathbf{m}^{2}\end{array}$ & $\begin{array}{l}\% \text { area } \\
\text { change }^{1}\end{array}$ & $\begin{array}{l}\text { No. of } \\
\text { plants }\end{array}$ \\
\hline $\begin{array}{l}\text { Altcar Training Camp } \\
\text { scrape } 8^{*}\end{array}$ & SD28640498 & Semi-aquatic & 28.3 & - & 55 \\
\hline $\begin{array}{l}\text { Altcar Training Camp } \\
\text { scrape } 8^{*}\end{array}$ & SD28660504 & $\begin{array}{l}\text { Wet-slack/semi- } \\
\text { aquatic }\end{array}$ & 78.6 & - & 375 \\
\hline $\begin{array}{l}\text { Altcar Training Camp } \\
\text { scrape 5* }\end{array}$ & SD28620458 & Wet-slack & 227 & - & 450 \\
\hline Altcar Training Camp & SD28870462 & Damp grassland & $?$ & $?$ & 2 \\
\hline Cabin Hill NNR slack 1 & SD28260528 & Wet-slack & 921 & -23 & 1000 \\
\hline Cabin Hill NNR slack 3 & SD28350529 & Wet-slack & 33.2 & -39 & 50 \\
\hline Cabin Hill NNR slack 20 & SD28250521 & Wet-slack & 9.6 & -71 & 20 \\
\hline Devil's Hole* & SD27830541 & Wet-slack & 3.1 & - & 10 \\
\hline $\begin{array}{l}\text { Sands Lake carpark, } \\
\text { Birkdale frontals (south) }\end{array}$ & SD30131282 & Dry-slack & 18 & -22 & 275 \\
\hline $\begin{array}{l}\text { Birkdale frontals (south) } \\
\text { pipeline slack* }\end{array}$ & SD30001301 & Dry-slack & 1 & - & 30 \\
\hline $\begin{array}{l}\text { Birkdale frontals (south) } \\
\text { slack } 51 / 52\end{array}$ & SD30011310 & Wet-slack & 53.5 & 84 & 200 \\
\hline $\begin{array}{l}\text { Birkdale frontals (south) } \\
\text { slack } 50\end{array}$ & SD30071316 & Wet-slack & 60.1 & -84 & 30 \\
\hline $\begin{array}{l}\text { Birkdale frontals (south) } \\
\text { slack } 49\end{array}$ & SD30091330 & Wet- slack & 11.8 & -92 & 155 \\
\hline Birkdale LNR slack 13* & SD30721362 & Wet-slack & 226 & - & 2000 \\
\hline $\begin{array}{l}\text { Royal Birkdale GC } 5^{\text {th }} \\
\text { fairway }\end{array}$ & SD31631529 & Damp grassland & 30 & -83 & 20 \\
\hline $\begin{array}{l}\text { Birkdale frontals (north) } \\
\text { slack } 27\end{array}$ & SD31341540 & Wet-slack & 115 & 98 & 725 \\
\hline $\begin{array}{l}\text { Birkdale frontals (north) } \\
\text { slack } 28\end{array}$ & SD314155 & Wet-slack & 300 & 85 & 1100 \\
\hline $\begin{array}{l}\text { Birkdale frontals (north) } \\
\text { slack } 30\end{array}$ & SD32031631 & Dry-slack & 60.1 & 7 & 300 \\
\hline $\begin{array}{l}\text { Birkdale frontals (north) } \\
\text { slack } 31\end{array}$ & SD31951619 & Wet-slack & 4.1 & -96 & 25 \\
\hline $\begin{array}{l}\text { Birkdale frontals (north) } \\
\text { slack } 32\end{array}$ & SD31911622 & Dry-slack & 154 & 144 & 5000 \\
\hline $\begin{array}{l}\text { Birkdale frontals (north) } \\
\text { slack } 33\end{array}$ & SD31931614 & Dry-slack & 86.6 & -49 & 500 \\
\hline $\begin{array}{l}\text { Queen's Jubilee Nature } \\
\text { Trail scrape* }\end{array}$ & SD32301683 & Wet-slack & 77 & - & 300 \\
\hline Total: 22 sites & & & 2498 & & 12622 \\
\hline
\end{tabular}




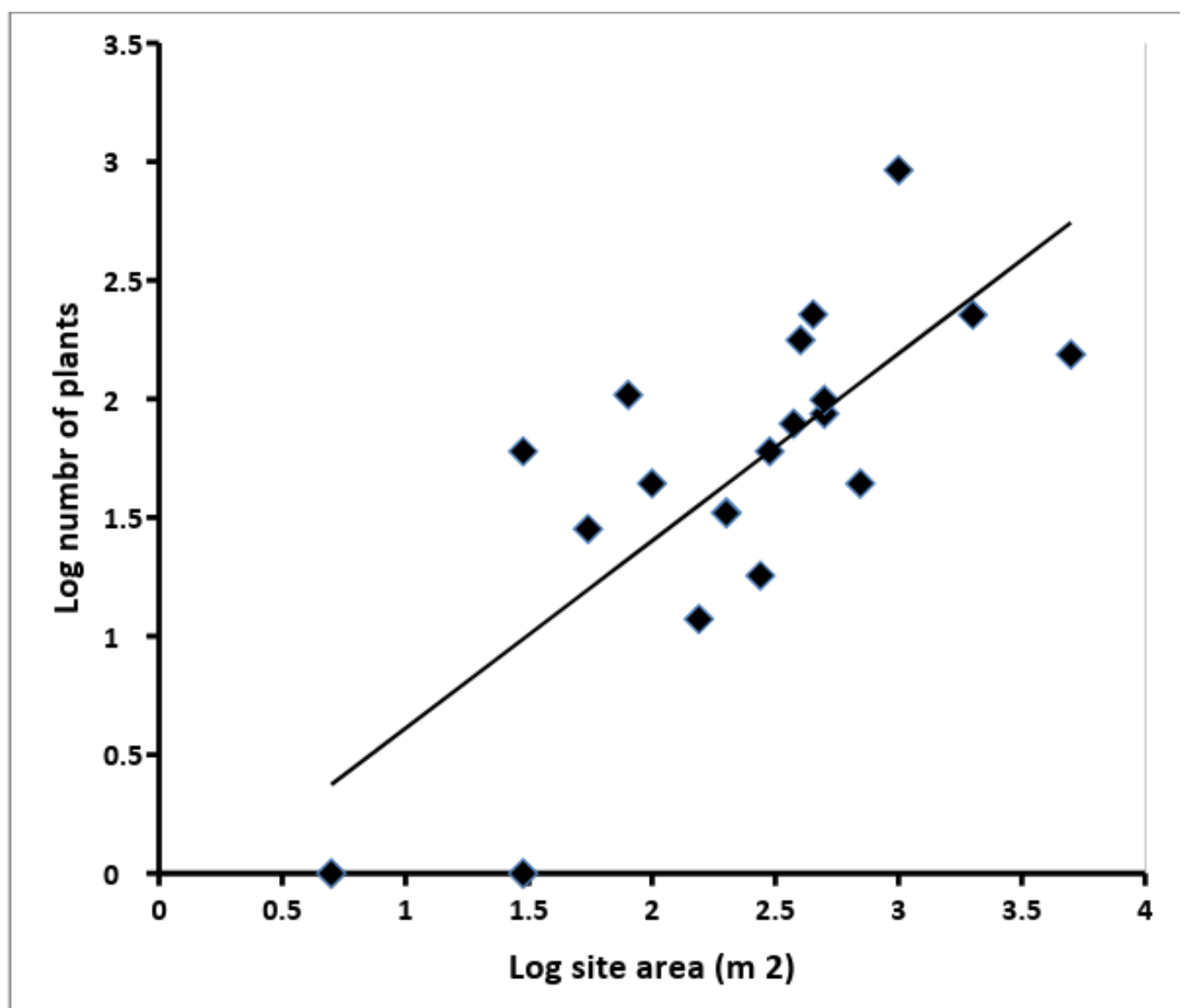

Figure 3. The relationship between $\log _{10}$ number of $B$. compressus plants and $\log _{10}$ site area $\left(m^{2}\right)(r=0.751 ; p=0.0001)$

Most Sefton Coast sites for $B$. compressus are dune-slacks that have formed secondarily by wind-erosion or by sand-winning and have a seasonally fluctuating water-table (Smith, 2009b). Using Ranwell's (1972) criteria for classifying slack-types, one site was considered to be semi-aquatic, one semi-aquatic/wet-slack, 13 wet-slack and five dryslack, while two were listed as damp grassland (Table 1). All the soil types were considered to be ground-water gleys of the Greatstone Series as defined by the Soil Survey of England \& Wales, though about half approached a peaty-gley condition with large amounts of surface organic matter (Beard et al., 1987). Soil pH was relatively high, ranging from 6.06 to 7.64 with a mean and standard deviation of 7.0 0.51 .

The 21 quadrats contained 80 vascular associates of $B$. compressus, those with the highest frequency being Agrostis stolonifera (Creeping Bent) (19 occurrences), Carex flacca (Glaucous Sedge) (15), Holcus lanatus (Yorkshire-fog) (11), Hydrocotyle vulgaris (Marsh Pennywort) (17), Plantago lanceolata (Ribwort Plantain) (10), Salix repens (Creeping Willow) (14) and Trifolium repens (White Clover) (13). Bryophytes were not studied in detail but five quadrats contained a high percentage cover of Calliergonella cuspidata (Pointed Spear-moss). The number of vascular taxa per quadrat ranged from 10 to 25 with a mean and standard deviation of $17.4 \pm 4.55$. Including $B$. 
compressus, ten of the taxa identified in quadrats are regionally or nationally notable, eight being Red-listed.

Mean vegetation height and standard deviation in quadrats was $18.5 \pm 7.5 \mathrm{~cm}$ (range 7-35 cm), while percentage cover of B. compressus varied from 3 to 30 (mean $10.3 \pm 7.8$ ). Samples with lower vegetation heights tended to have a higher cover of $B$. compressus (Fig. 4). Shorter swards were found in sites that were either subject to recreational trampling, vehicle passage or, more rarely, rabbit grazing. For example, slack 32 in the Birkdale frontals is situated at the junction of several informal footpaths and had the highest count of B. compressus (c.5000 plants). Here the vegetation was greatly suppressed by trampling, with an average height of $7 \mathrm{~cm}$ in quadrats (Fig. 5).

Similarly, slack 13 in Birkdale LNR is much visited by dog-walkers. Its large population of 2000 B. compressus plants was in wet-slack habitat on the northern side of a flooded excavated scrape. Being moderately trampled, this site had a mean sward height of $10 \mathrm{~cm}$, while the southern shore, which receives much higher visitor-pressure, was devoid of vegetation (Fig. 6). Being occasionally disturbed and rutted by military vehicles, three of the $B$. compressus sites at Altcar Training Camp had a mean vegetation height of $20 \mathrm{~cm}$ (Fig. 7). Birkdale slacks 28 and 27 were severely damaged by off-road vehicles in February 2014 (Fig. 8), both showing large area increases in $B$. compressus since 2008 (Table 1 ).

The most unusual locality was the edge of a carpark at Sands Lake, Ainsdale, where 275 plants were counted in a $1 \mathrm{~m}$-wide strip of heavily trampled weedy vegetation only $7 \mathrm{~cm}$ tall. This colony was also recorded in 2008, having been first noticed in 1979 (Smith, 2009a). B. compressus was also occasionally found in taller slack vegetation, stems of the plant being up to $47 \mathrm{~cm}$ long in slack 28, Birkdale frontals, slightly more than the maximum of $45 \mathrm{~cm}$ cited in Jermy et al. (2007). Rodwell (1991-2000) does not include $B$. compressus as a constituent of any NVC community. However, reference to his keys, data tables and community descriptions suggested that most quadrats had accordance with SD14: Salix repens-Campylium stellatum dune-slack (3 samples), SD15: Salix repens-Calliergon cuspidatum (now Calliergonella cuspidata) dune-slack (4 samples), SD16: Salix repens-Holcus lanatus dune-slack (4 samples) or SD17: Potentilla anserina-Carex nigra dune-slack (6 samples).

Two quadrats did not key out satisfactorily, while two had similarities to MG5: Cynosurus cristatus-Centaurea nigra grassland or MG6: Lolium perenne Cynosurus cristatus grassland. TABLEFIT analysis based on percentage cover of vascular taxa (Table 2) produced similar results with four samples having accordance with SD14, five with SD15, three with SD16 and four with SD17. One sample (Sands Lake carpark) resembled MG6: Lolium perenne-Cynosurus cristatus grassland, while the best fit for Birkdale slack 30 was MG8: Cynosurus cristatus-Caltha palustris grassland.

The two samples from the edge of the trampled scrape at Birkdale slack 13 resembled OV23: Lolium perenne-Dactylis glomerata weedy grassland and OV28: Agrostis stolonifera-Ranunculus repens muddy grassland. One sample from Birkdale slack 27 matched M22: Juncus subnodulosus-Cirsium palustre mire. However, all the samples showed "very poor" statistical fits to these vegetation types (Table 2). A re-run 
of TABLEFIT for vascular species presence gave identical NVC matches but levels of fit were higher, ranging from "very poor" to "very good" (Table 2).

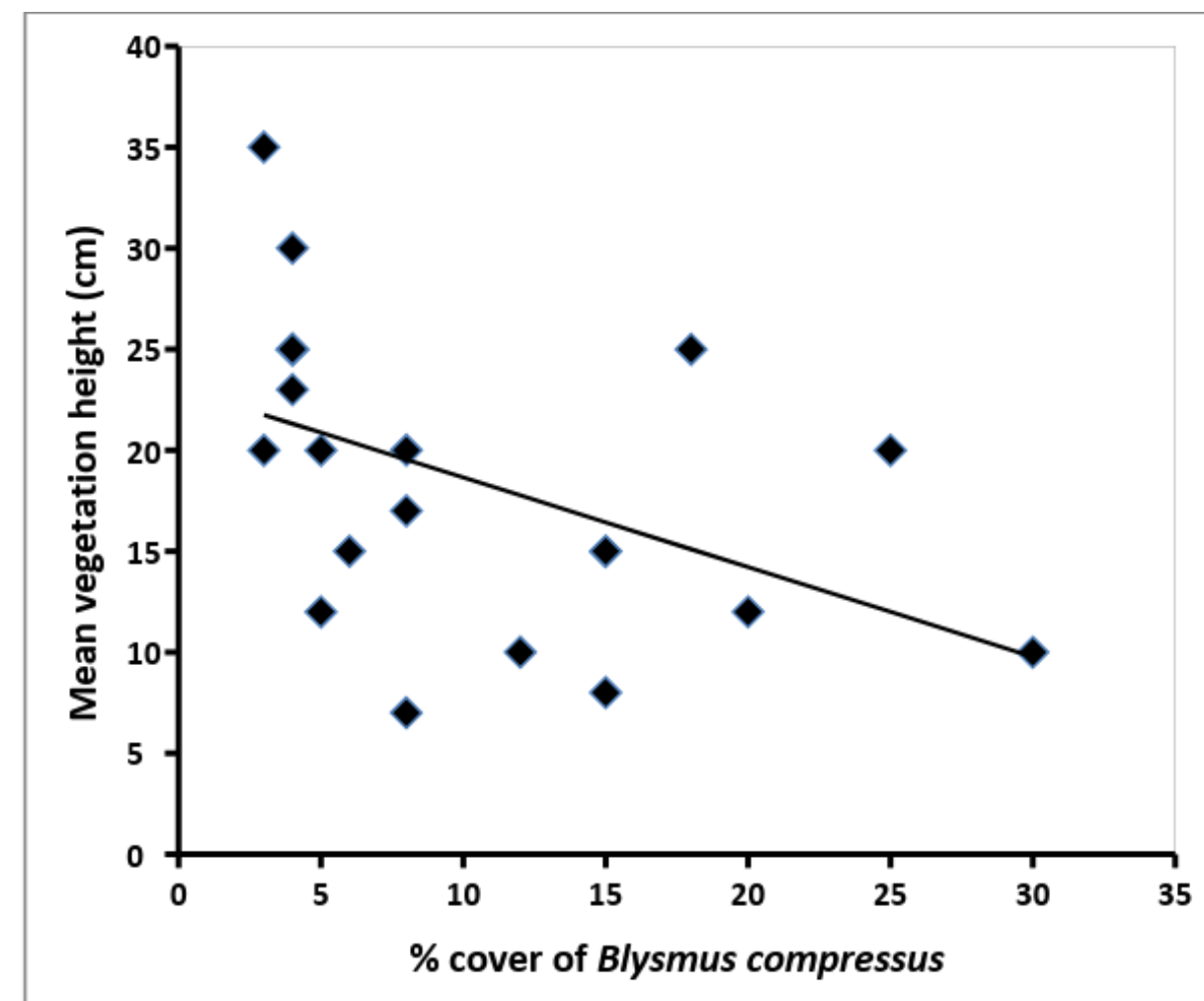

Figure 4. The relationship between mean vegetation height and \% cover of $B$. compressus in quadrats $(r=0.465 ; p=0.034)$

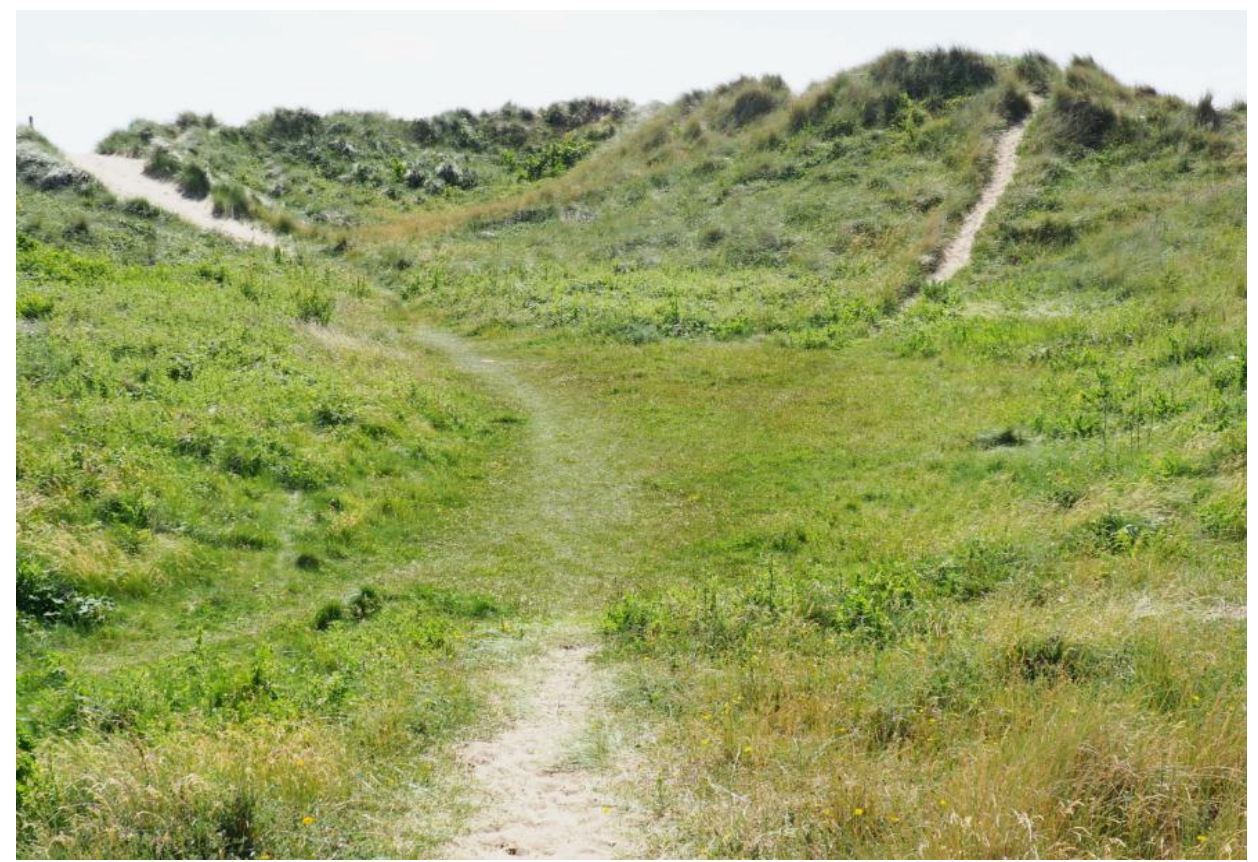

Figure 5. B. compressus habitat on informal footpaths at Birkdale slack 32 


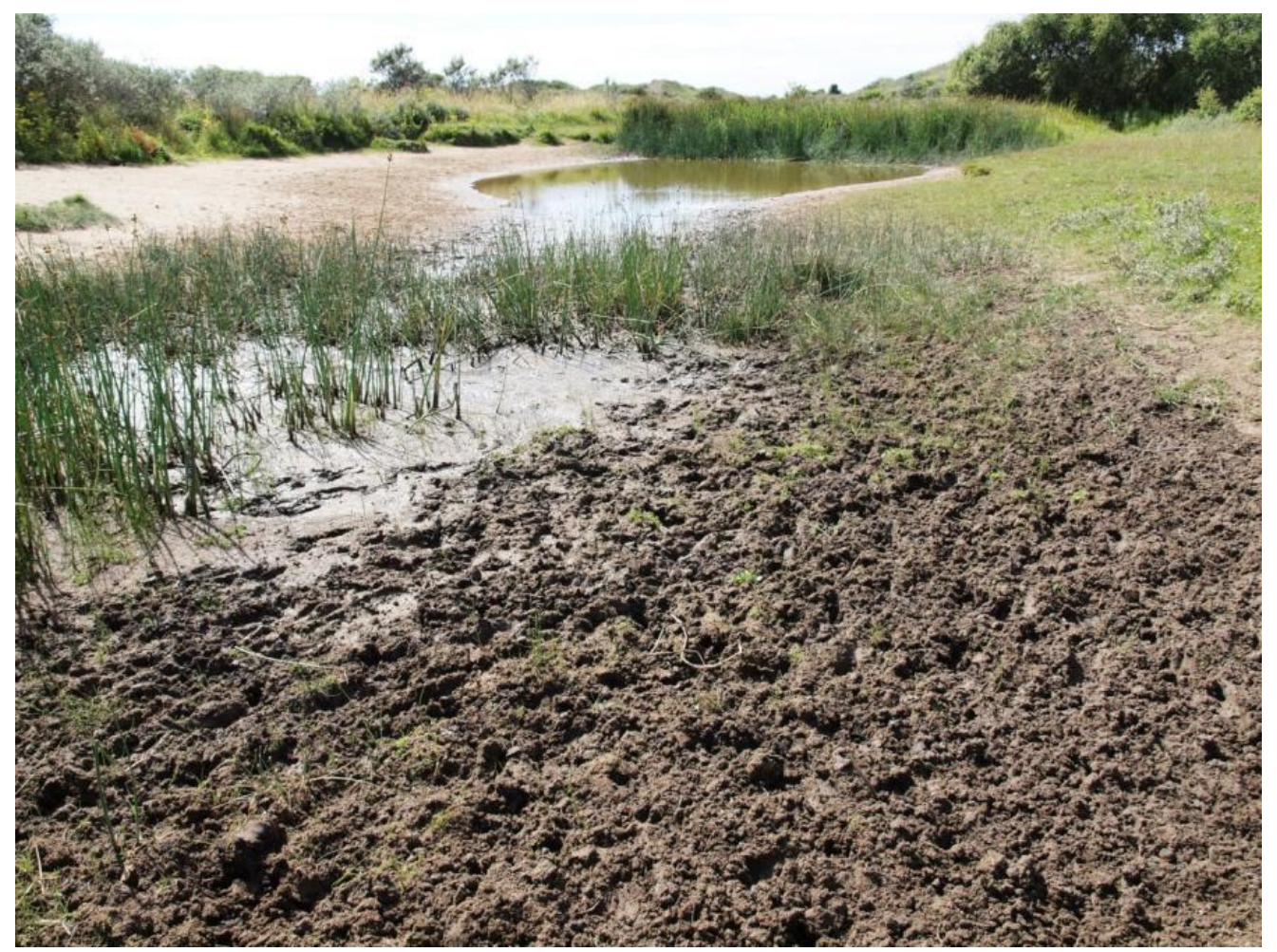

Figure 6. Heavy trampling at Birkdale Sandhills slack 13. B. compressus site upper right

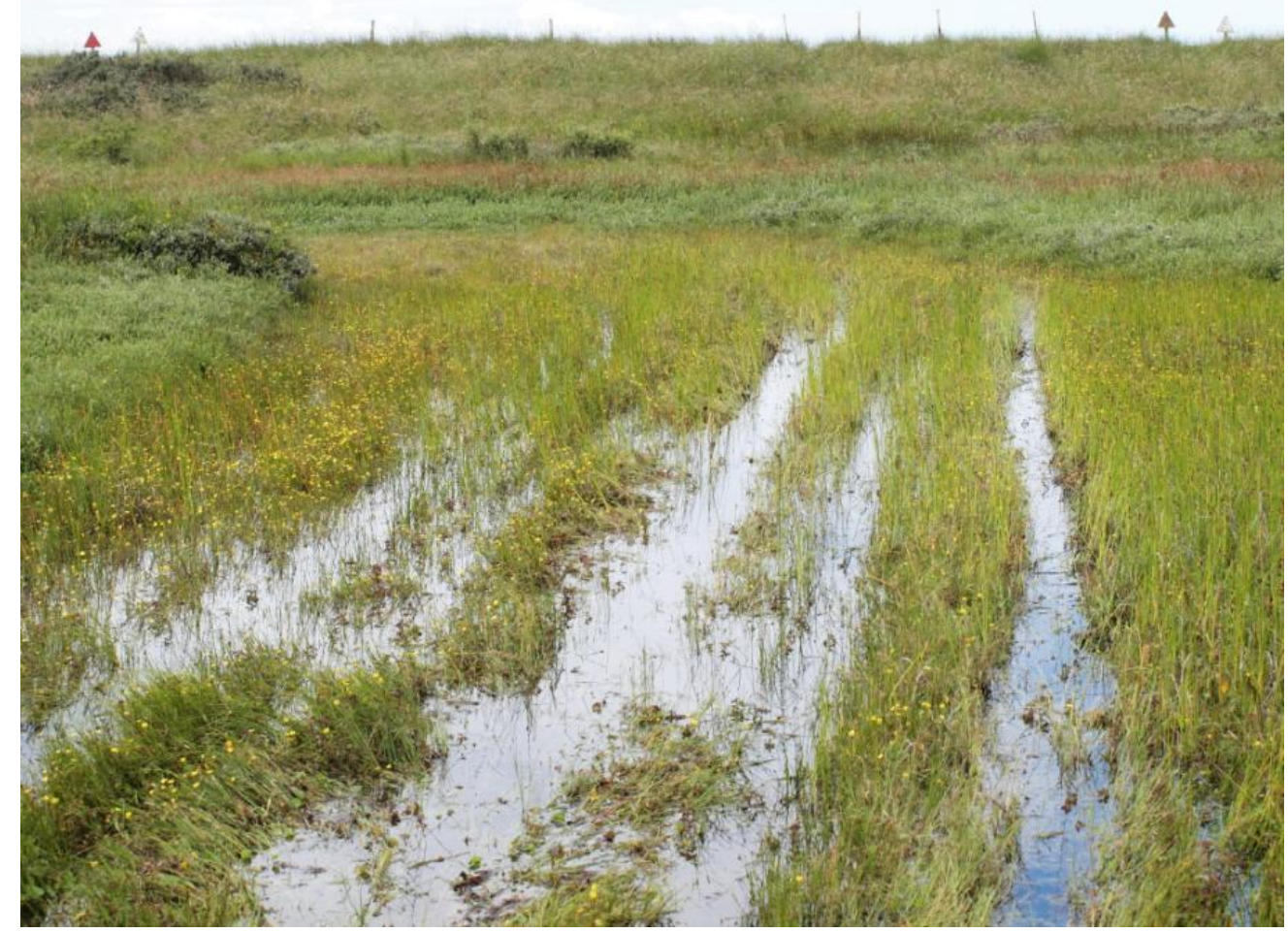

Figure 7. B. compressus site at Altcar Training Camp showing occasional use by military vehicles 


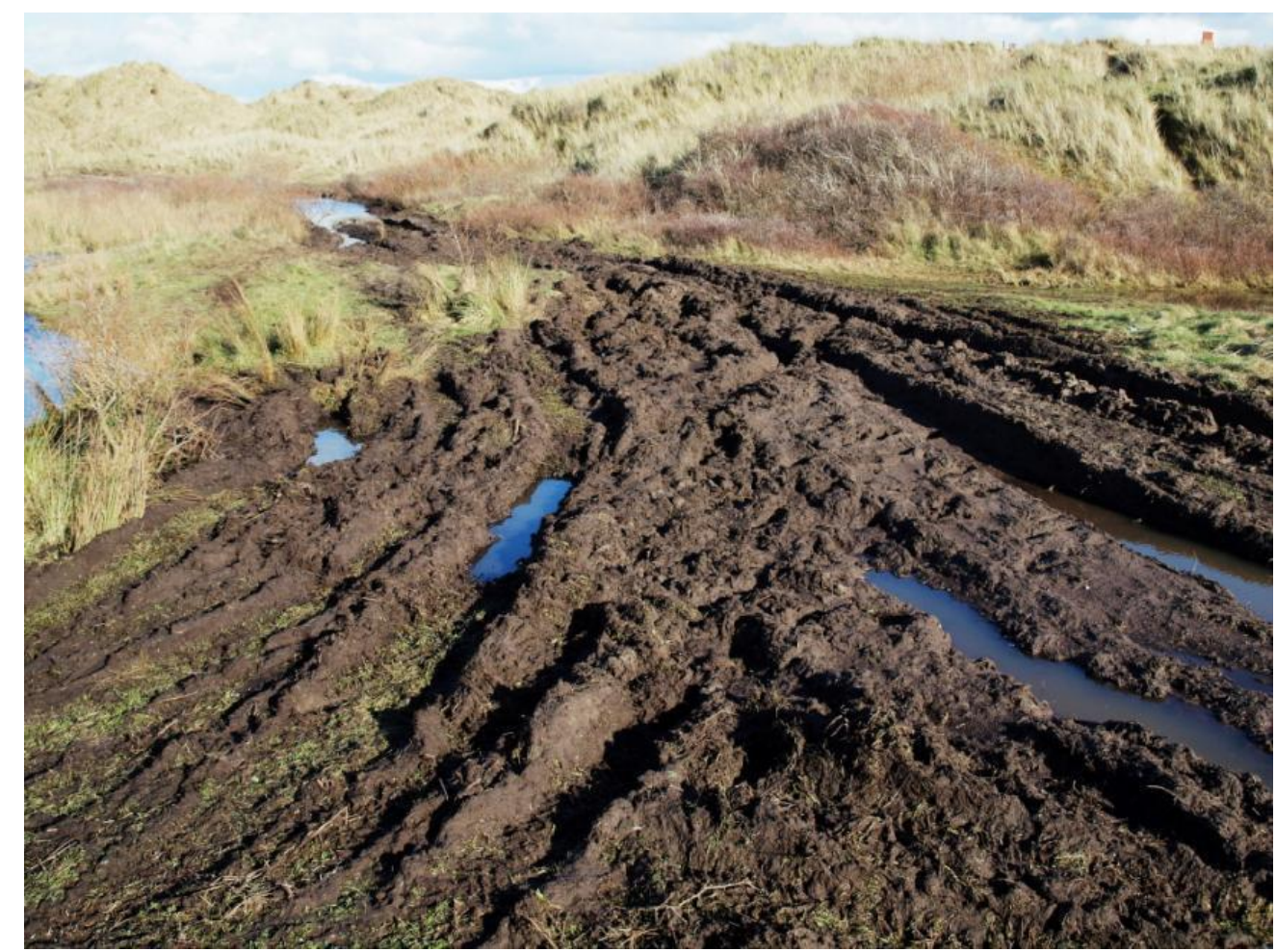

Figure 8. Unauthorised off-road vehicle damage, Birkdale slack 27, February 2014

Table 2. TABLEFIT analysis of quadrat samples

\begin{tabular}{|c|c|c|c|c|c|c|c|}
\hline $\begin{array}{l}\text { NVC } \\
\text { code }\end{array}$ & Community & $\begin{array}{l}\text { Sub- } \\
\text { community }\end{array}$ & $\begin{array}{l}\text { No. of } \\
\text { samples }\end{array}$ & $\begin{array}{l}\text { \% fit } \\
\text { cover }\end{array}$ & Match & $\begin{array}{l}\text { \% fit } \\
\text { species }\end{array}$ & Match \\
\hline SD14 & $\begin{array}{l}\text { Salix repens- } \\
\text { Campylium } \\
\text { stellatum dune } \\
\text { slack }\end{array}$ & & 1 & 22 & $\begin{array}{l}\text { Very } \\
\text { poor }\end{array}$ & 44 & $\begin{array}{l}\text { Very } \\
\text { poor }\end{array}$ \\
\hline SD14d & $\begin{array}{l}\text { Salix repens- } \\
\text { Campylium } \\
\text { stellatum dune } \\
\text { slack }\end{array}$ & Festuca rubra & 3 & $29-36$ & $\begin{array}{l}\text { Very } \\
\text { poor }\end{array}$ & $59-73$ & $\begin{array}{l}\text { Poor- } \\
\text { good }\end{array}$ \\
\hline SD15 & $\begin{array}{l}\text { Salix repens- } \\
\text { Calliergon } \\
\text { cuspidatum } \\
\text { dune slack }\end{array}$ & & 3 & $21-46$ & $\begin{array}{l}\text { Very } \\
\text { poor }\end{array}$ & $43-93$ & $\begin{array}{l}\text { Very } \\
\text { poor- } \\
\text { very } \\
\text { good }\end{array}$ \\
\hline SD15a & $\begin{array}{l}\text { Salix repens- } \\
\text { Calliergon } \\
\text { cuspidatum } \\
\text { dune slack }\end{array}$ & Carex nigra & 1 & 24 & $\begin{array}{l}\text { Very } \\
\text { poor }\end{array}$ & 49 & $\begin{array}{l}\text { Very } \\
\text { poor }\end{array}$ \\
\hline SD15b & $\begin{array}{l}\text { Salix repens- } \\
\text { Calliergon } \\
\text { cuspidatum }\end{array}$ & $\begin{array}{l}\text { Equisetum } \\
\text { variegatum }\end{array}$ & 1 & 29 & $\begin{array}{l}\text { Very } \\
\text { poor }\end{array}$ & 59 & Poor \\
\hline
\end{tabular}




\begin{tabular}{|c|c|c|c|c|c|c|c|}
\hline & dune slack & & & & & & \\
\hline SD16b & $\begin{array}{l}\text { Salix repens- } \\
\text { Holcus } \\
\text { lanatusdune } \\
\text { slack }\end{array}$ & $\begin{array}{l}\text { Rubus } \\
\text { caesius }\end{array}$ & 2 & $33-36$ & $\begin{array}{l}\text { Very } \\
\text { poor }\end{array}$ & $66-72$ & $\begin{array}{l}\text { Fair- } \\
\text { good }\end{array}$ \\
\hline SD16d & $\begin{array}{l}\text { Salix repens- } \\
\text { Holcus lanatus } \\
\text { dune slack }\end{array}$ & $\begin{array}{l}\text { Agrostis } \\
\text { stolonifera }\end{array}$ & 1 & 34 & $\begin{array}{l}\text { Very } \\
\text { poor }\end{array}$ & 69 & Fair \\
\hline SD17 & $\begin{array}{l}\text { Potentilla } \\
\text { anserina-Carex } \\
\text { nigra dune } \\
\text { slack }\end{array}$ & & 1 & 32 & $\begin{array}{l}\text { Very } \\
\text { poor }\end{array}$ & 65 & Fair \\
\hline SD17b & $\begin{array}{l}\text { Potentilla } \\
\text { anserina-Carex } \\
\text { nigra dune } \\
\text { slack }\end{array}$ & Carex flacca & 1 & 31 & $\begin{array}{l}\text { Very } \\
\text { poor }\end{array}$ & 63 & Fair \\
\hline SD17d & $\begin{array}{l}\text { Potentilla } \\
\text { anserina-Carex } \\
\text { nigra dune } \\
\text { slack }\end{array}$ & $\begin{array}{l}\text { Hydrocotyle } \\
\text { vulgaris- } \\
\text { Ranunculus } \\
\text { flammula }\end{array}$ & 2 & $38-45$ & $\begin{array}{l}\text { Very } \\
\text { poor }\end{array}$ & $77-91$ & $\begin{array}{l}\text { Good- } \\
\text { very } \\
\text { good }\end{array}$ \\
\hline MG6a & $\begin{array}{l}\text { Lolium } \\
\text { perenne- } \\
\text { Cynosurus } \\
\text { cristatus } \\
\text { grassland }\end{array}$ & Typical & 1 & 29 & $\begin{array}{l}\text { Very } \\
\text { poor }\end{array}$ & 58 & Poor \\
\hline MG8 & $\begin{array}{l}\text { Cynosurus } \\
\text { cristatus-Caltha } \\
\text { palustris } \\
\text { grassland }\end{array}$ & & 1 & 30 & $\begin{array}{l}\text { Very } \\
\text { poor }\end{array}$ & 61 & Fair \\
\hline M22 & $\begin{array}{l}\text { Juncus } \\
\text { subnodulosus- } \\
\text { Cirsium } \\
\text { palustre mire }\end{array}$ & & 1 & 20 & $\begin{array}{l}\text { Very } \\
\text { poor }\end{array}$ & 40 & $\begin{array}{l}\text { Very } \\
\text { poor }\end{array}$ \\
\hline OV23c & $\begin{array}{l}\text { Lolium } \\
\text { perenne- } \\
\text { Dactylis } \\
\text { glomerata } \\
\text { weedy } \\
\text { grassland }\end{array}$ & $\begin{array}{l}\text { Plantago } \\
\text { major- } \\
\text { Trifolium } \\
\text { repens }\end{array}$ & 1 & 28 & $\begin{array}{l}\text { Very } \\
\text { poor }\end{array}$ & 56 & Poor \\
\hline OV28a & $\begin{array}{l}\text { Agrostis } \\
\text { stolonifera- } \\
\text { Ranunculus } \\
\text { repens muddy } \\
\text { grassland }\end{array}$ & $\begin{array}{l}\text { Polygonum } \\
\text { hydropiper- } \\
\text { Rorippa } \\
\text { sylvestris }\end{array}$ & 1 & 22 & $\begin{array}{l}\text { Very } \\
\text { poor }\end{array}$ & 45 & $\begin{array}{l}\text { Very } \\
\text { poor }\end{array}$ \\
\hline
\end{tabular}




\section{Discussion}

Almost all of the $B$. compressus localities are in seasonally-flooded, calcareous dune-slacks where the plant is subject to occasional inundation by base-rich freshwater. Waterlogged conditions seem to favour this species (Jermy et al., 2007; Walker et al., 2017), perhaps because tolerating oxygen deficiency in the soil gives it a competitive advantage (Stroh \& Walker, 2015). The target species was restricted to about $2500 \mathrm{~m}^{2}$ of dune-slack and damp grassland. This is a small proportion of the potentially available habitat, the Sefton Coast having over 114 ha of slacks and freshwater wetland, amounting to $33 \%$ of the dune-slack resource in England (Edmondson, 2010; Radley, 1994). However, many of the slacks originated over 100 years ago and, being heavily vegetated (Smith, 2009b), are probably unsuitable for $B$. compressus.

Distances between the three groups of sites supporting the plant are approximately $12 \mathrm{~km}$ and $2.8 \mathrm{~km}$, suggesting that dispersal and establishment of new colonies may be problematic. Little seems to be known about dispersal mechanisms in this species (Stroh \& Walker, 2015), though Pignotti \& Mariotti (2004) described particularly long perianth bristles surrounding the nut that may assist attachment to mammals and birds.

Smith (2009a) reported "encouraging findings" that fewer than ten sites in the Sefton dunes for $B$. compressus in the early 1980 s had increased to 18 by 2008 . Only two sites had been lost since the 1970s. However, considerable changes have taken place in the distribution and abundance of $B$. compressus in the decade since the 2008 survey. First, seven new colonies were found, representing $25.7 \%$ and $25.5 \%$ of the current total area and population, respectively. Nevertheless, there has been an overall reduction in abundance and colony size. An estimated 15-20,000 plants in the earlier survey declined to 12,600 ten years on. Similarly, the total area of sites occupied by $B$. compressus fell by $17 \%$, despite the addition of new sites. Many of the surviving sites are small, $73 \%$ supporting $\leq 1000$ plants, while $64 \%$ are $\leq 100 \mathrm{~m}^{2}$ in area. This makes them potentially vulnerable to habitat change.

Walker et al. (2017) concluded that $B$ compressus was highly susceptible to competition from taller-growing plants, the main threats being absence of grazing or cutting, changes to the hydrological regime and repeated disturbance by vehicles or people causing trampling and soil compaction. Smith (2009a) provided evidence that most of the $B$. compressus sites on the Sefton dunes were of fairly recent origin and had a history of recreational disturbance and grazing, especially by rabbits. Some were winter-grazed by livestock and others had been mowed annually. All the newly discovered locations are also relatively young. The three Altcar sites are in scrapes dug in 1976, the Birkdale pipeline slack was formed by wind-erosion in the mid-late 1970s, the Birkdale slack 13 population borders a scrape excavated in 1977 and the Queen's Jubilee population is in a 1994 scrape. The youngest is the Devil's Hole, a dune blowout in which slack vegetation began to colonise in 2003, B. compressus being found in 2015 (Smith, 2017a). Thus, none of these habitats is much more than 40 years old, though the fact that $B$. compressus did not appear in the Devil's Hole until 12 years of vegetation development suggests that it is not a pioneer species. As slacks age, their 
initially open plant communities become colonised by coarser, taller vegetation, including shrub species (Rodwell, 1991-2000; Davy et al., 2006). B. compressus is therefore likely to decline in older slacks unless these are managed to maintain short swards which this study has shown are associated with higher frequencies of the plant.

An Ellenberg $\mathrm{N}$ value of 3 indicates adaptation of $B$. compressus to infertile conditions (Hill et al., 2004). Millington et al. (2010) showed that Sefton dune soils generally have relatively low nitrogen levels which tends to increase in the older parts of the system. Increases in nitrogen and other nutrients in dune-slack soils during succession is well-established (e.g. Grootjans et al., 1998; Olff et al., 1993), probably making older slacks less suitable for $B$. compressus. Eutrophication is likely to be exacerbated by aerial deposition of nitrogen from industrial and agricultural sources (Jones et al., 2004).

Although Walker et al. (2017) highlight soil compaction and trampling damage as a threat to the plant, Smith (2009a) found that human trampling benefited $B$. compressus by reducing sward height and the dominance of Salix repens. This was also apparent in the current study, the heavily trampled slack 32 in the Birkdale frontals (Fig. 5) having both the largest population of $B$. compressus and the greatest increase since 2008. Vegetation height at the important colony at Birkdale slack 13 was similarly reduced by recreational pressure (Fig. 6). As in 2008, several sites were associated with the edges of informal footpaths where vegetation, especially $S$. repens, has been suppressed (Fig. 9). Examples include the Birkdale pipeline slack, frontal slacks 27, 28, 33 and 51/52 and the heavily disturbed fringe of Sands Lake carpark. Smith (2009a) described the latter site as "sub-optimal" for $B$. compressus, expressing surprise that the plant had survived here since 1979. He also found that it had persisted and increased after severe churning by illegal motor-cycling in the northern Birkdale frontal slacks during the late 1970 s and early 1980 s. Occasional passage of military vehicles similarly created more open, disturbed swards at some of the Altcar sites (Fig. 7), while off-road vehicle damage to Birkdale slacks 27 and 28 in 2014 (Fig. 8) was followed by an increase in $B$. compressus. The loss of the Birkdale slack 26 population and declines at slacks 49,50 and 31 seem to be partly associated with reduced footfall and the overgrowth of informal footpaths by coarse vegetation dominated by tall $S$. repens. K. Walker (personal communication, 2008) reported that the densest populations of $B$. compressus he found in the Yorkshire Dales National Park, including thousands of plants at Gordale Scar campsite, were hard-grazed or kept open by trampling. It was also apparent that four sites in the Birkdale frontals (slacks 30, 31, 50 and 51/52) were being colonised by larger shrub species: Hippophae rhamnoides (Sea Buckthorn) and Salix cinerea (Grey Willow) (Fig. 10). This may have contributed to declines of $B$. compressus at slacks 31 and 50. Smith (2009a) also drew attention to the growth of larger willow taxa as a potential threat to $B$. compressus.

Annual late-summer mowing of sites at Altcar Rifle Range, Ainsdale slack 49 and Royal Birkdale was highlighted by Smith (2009a) as a way of maintaining lower sward heights. Mowing has continued at Altcar "I" range and Royal Birkdale but seemingly did not prevent a decline of $B$. compressus at the golf course $5^{\text {th }}$ fairway. This grassland is rarely inundated in winter and may now be too dry for the plant to thrive. 
The Cabin Hill NNR sites and Birkdale slack 13 are winter-grazed by livestock but a large rabbit population at Cabin Hill that helped to maintain shorter swards throughout the year has declined to near extinction, probably due to disease. Formerly supporting the largest duneland population of $B$. compressus, the number of plants at Cabin Hill's site 1 has fallen by about $90 \%$. This site was mowed on four occasions in the 1990s but less often since and most recently in 2011/12 and 2017/18. Birkdale frontal slack 49, which has lost $92 \%$ of its colony area, was mowed annually, with removal of arisings, from 1996 to about 2010 but not subsequently. Slack 49 had a moderate rabbit population in 2008 (Smith, 2009a) but rabbit activity was noted only at Devil's Hole during the 2018 survey. These grazers are known to have a major influence on sanddune vegetation, including seed dispersal (Dellafiore et al., 2010; Potter \& Hosie, 2001) but tend to be excluded once coarse vegetation becomes established (Drees \& Olff, 2001).

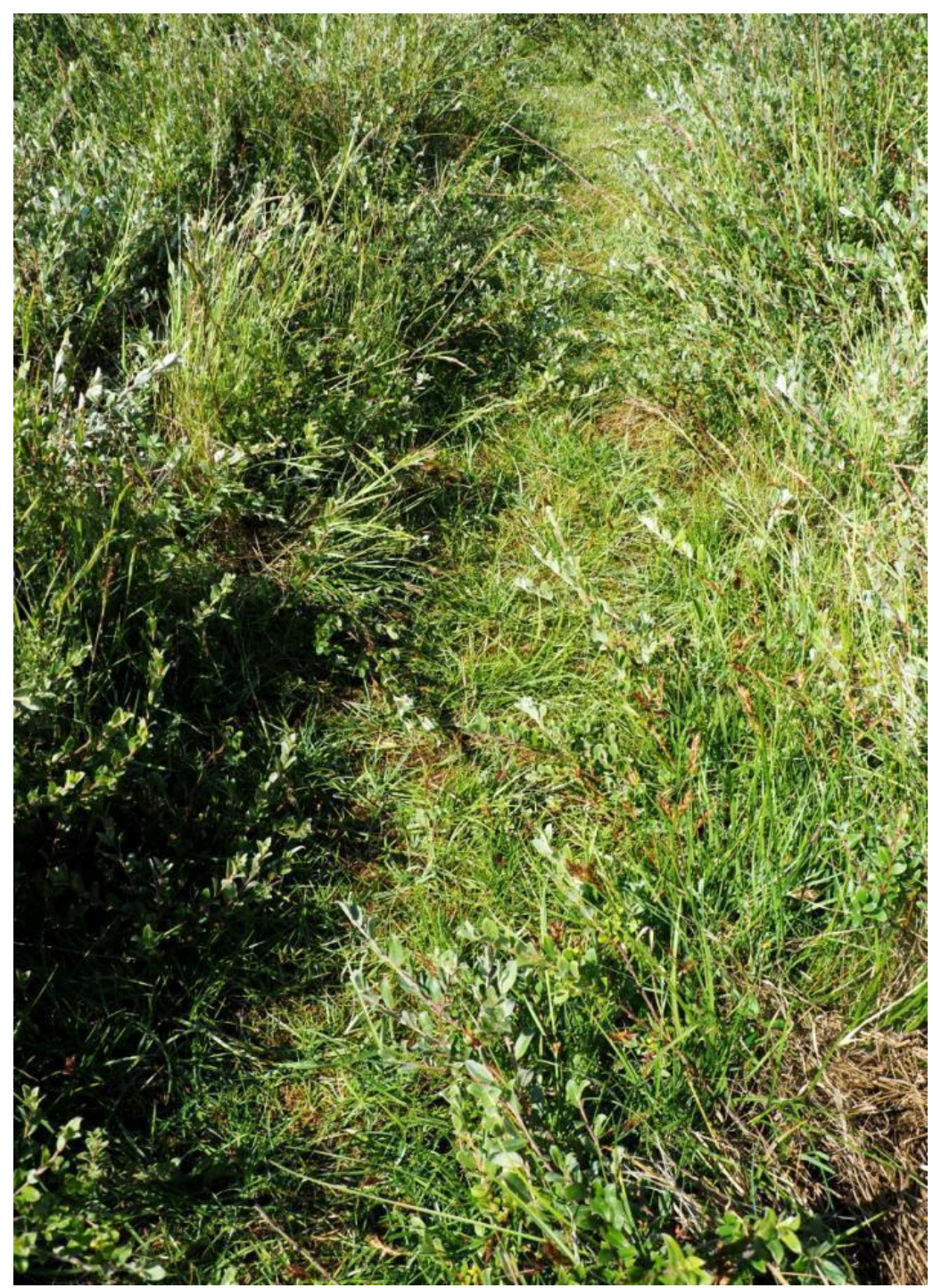

Figure 9. B. compressus on an informal footpath through Salix repens-dominated vegetation 


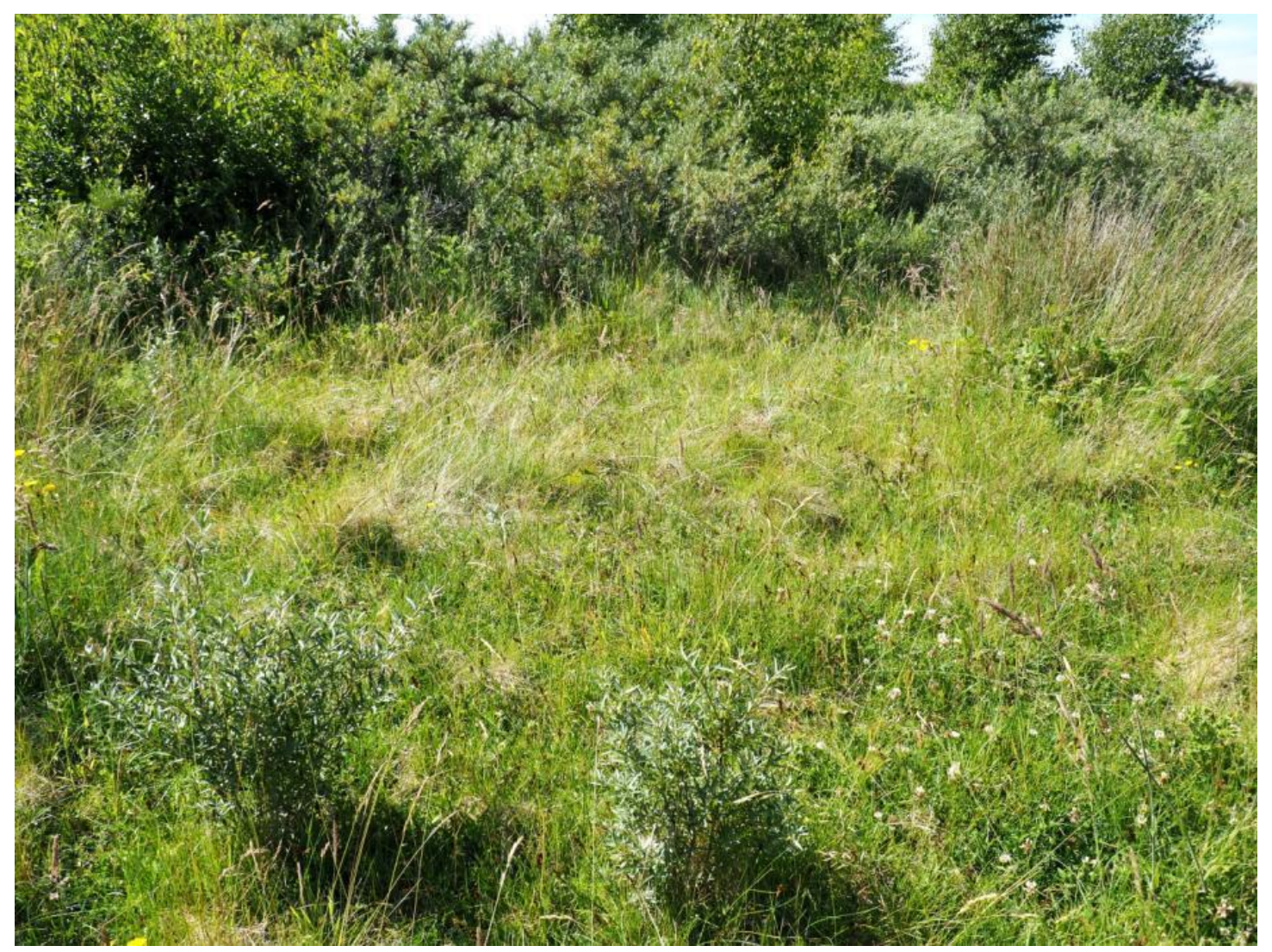

Figure 10. Scrub invasion of $B$. compressus site at Birkdale slack 33

Relatively high values for soil pH measured in this study are similar to those published by Millington et al. (2010) for Sefton Coast dune-slacks, reflecting the presence of calcium carbonate derived from marine mollusc shells. However, these authors included a number of older and more acidic slacks in their samples. Their mean $\mathrm{pH}$ value of 6.7 is therefore lower than the 7.0 found in the younger slacks supporting B. compressus. An Ellenberg reaction value of 8 (Hill et al., 2004) confirms the association of this plant with base-rich soils, as reported more widely (Stroh \& Walker, 2015; Walker et al., 2017).

Blysmus compressus habitats were found to support a diverse plant community, 80 associated vascular taxa being recorded in 21 quadrats, compared with 90 in 51 quadrats during the 2008 survey. Of the most frequent associates, all except Plantago lanceolata were also ubiquitous in the 2008 quadrats (Smith, 2009a). A high speciesrichness is characteristic of many younger dune-slacks on the Sefton Coast (Smith, 2006). The slacks are also renowned for their rare plants, nine associated taxa in 2018 $(11 \%)$ being regionally or nationally notable, the comparable figure in 2008 being 12 $(13 \%)$. Remarkably, only two taxa (2.5\%) found were non-native, in contrast to the Sefton sand-dune flora as a whole, which has about $37 \%$ alien vascular plants (Smith, 2015).

The allocation of most 2018 quadrats to SD14, SD15, SD16 or SD17 accords with the earlier survey which found that $37 \%$ of samples equated to SD16, $27 \%$ to SD15 and $18 \%$ to SD17 (Smith, 2009a). That study also recorded a small number of samples 
with a best fit to MG11: Festuca rubra-Agrostis stolonifera-Potentilla anserina grassland or MG8: Cynosurus cristatus-Caltha palustris grassland (Rodwell, 1991-2000). However, most of the matches were "poor" or "very poor". As previously noted, $B$. compressus is not given as a component of NVC sand-dune slack communities by Rodwell (1991-2000). Walker et al. (2017) report that most populations of $B$. compressus recorded during the Threatened Plants Project were in fen meadows and rush pastures, especially M22: Juncus subnodulosus-Cirsium palustre fen-meadow, M24: Molinia caerulea-Cirsium dissectum fen meadow, M26: Molinia caerulea-Crepis paludosa mire and MG8: Cynosurus cristatus-Caltha palustris grassland. Fen meadows and rush pastures are not typically associated with calcareous sand-dunes (Rodwell, 1991-2000). The 2003/04 NVC survey of the Sefton Coast mapped only 0.03 ha of M22, consisting of dense patches of Juncus subnodulosus (Blunt-flowered Rush) (Gateley \& Michell, 2004). The present study noted a few stems of $B$. compressus on the edge of one of these patches at the Devil's Hole but this association was not found during a coastwide survey of J. subnodulosus in 2013 (Smith, 2014). B. compressus seems unlikely to be able to compete with dense stands of J. subnodulosus (Walker et al., 2017). TABLEFIT analysis determined one 2018 sample (Birkdale slack 27) as M22 but statistical matches were "very poor" for both percentage cover and species only. Hill (2015) recommends that if goodness-of-fit is "very poor" the vegetation should probably not be assigned to any NVC type. The same should perhaps apply to the two OV communities ascribed by TABLEFIT to Birkdale slack 13. Percentage cover gave "very poor" fits while, for species only, the matches were "poor" to "very poor".

Poor statistical fits to NVC communities have been found in several previous studies of Sefton Coast vegetation (Smith, 2017b). This may be due to the complex environmental gradients that operate in dune systems, to the difficulty in selecting "typical" stands in the mosaic of dune vegetation and the fact that the data used to derive dune NVC communities were based on a limited number of quadrats and may not be particularly representative (Natural England, 2014).

\section{Conservation}

Colonies of $B$. compressus on the Sefton Coast are mostly found in younger duneslacks, in which succession is likely to reduce habitat suitability over time. Due to overstabilisation, there is a low rate of slack formation on the Sefton Coast (Smith, 2009b), with limited potential for suitable new habitat to form without human intervention. Since the mid-1980s, a 66 ha mosaic of saltmarsh, embryo dunes and slacks, known as Birkdale Green Beach, has developed on the shore between Birkdale and Ainsdale (Smith, 2007). Smith (2009a) suggested that this might provide suitable habitat for $B$. compressus. However, despite careful searches, only the related B. rufus (Saltmarsh Flat-sedge) has been found there.

As more than $60 \%$ of the B. compressus colonies known in 2008 have declined over the last decade, active management is likely to be needed to prevent further losses. Walker et al. (2017) recommend maintaining an open, short sward, a dynamic hydrological regime and reducing eutrophication. The current study suggests that these approaches could help to conserve $B$. compressus in the Sefton dunes and would have 
wider benefits, as the slack habitat supporting $B$ compressus is rich in other biota (Smith, 2009b).

Shorter swards in slacks can be achieved by livestock grazing and mowing (Houston, 2008), while the present study shows that light to moderate recreational trampling or low levels of vehicle use can have the same effect. However, only four of the 22 sites recorded in 2018 are within Sefton duneland units grazed by livestock. Rabbits have greatly declined in recent years and resources for mowing slacks have been much reduced since about 2010. Tramping tends to be concentrated near to access points and its intensity is difficult to manage, over-use being deleterious (Walker et al., 2017). Colonies threatened by scrub invasion, especially of Hippophae rhamnoides, Salix cinerea and $S$. repens require targeted scrub control. In recent years, this has relied increasingly on volunteers using hand-tools, rather than the machinery needed to tackle older and larger scrub patches.

Turf-stripping to return slacks to an earlier successional stage has been used on the Sefton Coast to create over 50 small breeding pools (scrapes) for Natterjack Toads (Epidalea calamita) (Smith, 2009b). This has benefited some early successional stage slack plants, such as Carex oederi (Small-fruited Yellow-sedge) (Smith, 2017b). Decleer (2008) reports the appearance of B. compressus after large-scale restoration of dune slacks in Belgium, suggesting colonisation from a long-lived seed-bank. However, the plant was found in only four Sefton scrapes and not as a pioneer. Turf-stripping, mowing and grazing may help to counter eutrophication, though Plassmann et al. (2009) showed that, while it helped to keep competitive grasses in check and maintain species-rich swards, duneland grazing did not mitigate all the negative effects of $\mathrm{N}$ deposition.

Detailed hydrological studies provide no evidence of a consistent decline in the Sefton sand-dune water-table over the last 46 years (Clarke \& Sanitwong Na Ayutthaya, 2010). However, Natural England (2014) found a $36 \%$ and $44 \%$ reduction in wetland area at Ainsdale and Birkdale respectively between 1989 and 2012 due to slack habitats becoming drier. Climate change may cause average dune water-levels to fall by as much as $1.5 \mathrm{~m}$ by the end of the century (Clarke \& Sanitwong Na Ayutthaya, 2010), giving rise to concerns for the long-term future of slack species, including $B$. compressus.

It is hoped that two coast-wide projects will augment funding for dune management and contribute to conservation of $B$. compressus and other threatened Sefton dune biota. Part of the Back from the Brink project supported by Heritage Lottery (HLF) and other partners, Gems in the Dunes targets six Section 41 species for recovery management in the dunes. $B$. compressus is one of the secondary targets for the project which runs from 2017 to 2020 . Relevant management includes scrub control, small-scale turf-stripping and scrape creation, as well as public engagement to encourage survey work, monitoring and volunteer recruitment. Dynamic Dunescapes is a joint HLF and EU Life project covering seven coastal dune systems in England and Wales, including the Sefton Coast. The delivery phase, from 2019 to 2023, proposes capital works, such as re-mobilisation, turf-stripping, mowing and scrub control. There is also an emphasis on public involvement and citizen science. However, both these 
initiatives are time-limited. A longer-term vision for duneland management is provided by the Sefton Coast Plan (https://indd.adobe.com/view/88432262-8368-42b2-8d9197ef25ddec4c) and a Nature Conservation Strategy, currently being developed by the Sefton Coast Landscape Partnership.

\section{Acknowledgements}

I am grateful to Patricia Lockwood for field assistance, to Joshua Styles for the distribution map and to Natalie Hunt for TABLEFIT analysis and copies of some references. Col. Gordon Black kindly gave permission for access to Altcar Training Camp. Mike Wilcox suggested helpful changes to a draft manuscript.

\section{References}

Beard, C.R., Thompson, T.R.E. \& Lea, J.W. 1987. Soils of the Liverpool district. Harpenden: Memoirs of the Soil Survey of England and Wales.

Cheffings, C.M. \& Farrell, L. eds. 2005. The vascular plant red data list for Great Britain. Peterborough: Joint Nature Conservation Committee.

Clarke, D. \& Sanitwong Na Ayutthaya, S. 2010. Predicted effects of climate change, vegetation and tree cover on dune slack habitats at Ainsdale on the Sefton Coast, UK. Journal of Coastal Conservation, 14: 115-125.

Davy, A.J., Grootjans, A.P., Hiscock, K. \& Petersen, J. 2006. Development of ecohydrological guidelines for dune habitats - Phase 1. Peterborough: English Nature.

Decleer, K. ed. 2008. Ecological restoration in Flanders (Belgium). Ghent: Research Institute for Nature and Forest.

Dellafiore, C.M., Gallego Fernández, J.B. \& Muñoz Vallés, S. 2010. The rabbit (Oryctolagus cuniculus) as a seed disperser in a coastal dune system. Plant Ecology, 206: 251-261.

Dines, T. 2008. $A$ vascular plant red list for Wales. Salisbury: Plantlife International. Drees, M. \& Olff, H. 2001. Rabbit grazing and rabbit counting. In: Houston, J.A., Edmondson, S.E. \& Rooney, P.J. eds. Coastal dune management: shared experience of European conservation practice, 86-94. Liverpool: Liverpool University Press.

Edmondson, S.E. 2010. Dune slacks on the Sefton Coast. In: Worsley, A.T., Lymbery, G., Holden V.J.C. \& Newton, M. eds. Seftor's dynamic coast, pp.178-187. Southport: Sefton Technical Services Department.

Foley, M.J.Y. \& Porter, M.S. 2002. Blysmus compressus Flat-sedge. In: Preston, C.D., Pearman, D.A. \& Dines, T.D. eds. New atlas of the British and Irish flora, p.709. Oxford: Oxford University Press.

Gateley, P.S. \& Michell, P.E. 2004. Sand dune survey of the Sefton Coast. TEP, Warrington. Bootle: Sefton Metropolitan Borough Council.

Graham, G.G. 1988. The flora and vegetation of County Durham. Durham: the Durham Flora Committee and Durham County Conservation Trust. 
Grootjans, A.P., Ernst, W.H.O. \& Stuyfzand, P.J. 1998. European dune slacks: strong interactions of biology, pedogenesis and hydrology. Trends in Ecology and Evolution, 13: 96-100.

Halliday, G. 1997. A Flora of Cumbria. University of Lancaster: Centre for North-West Regional Studies.

Hill, M.O. 2015. Tablefit version 2.0 for identification of vegetation types. Wallingford: Centre for Ecology and Hydrology.

Hill, M.O., Preston, C.D. \& Roy, D.B. 2004. PLANTATT. Attributes of British and Irish plants. status, size, life history, geography and habitats. Monks Wood, Cambridgeshire: Centre for Ecology \& Hydrology.

Houston, J.A. 2008. Management of Natura 2000 habitats. 2190 humid dune slacks. Brussels: European Commission.

Jermy, A.C., Simpson, D.A., Foley, M.J.Y. \& Porter, M.S. 2007. Sedges of the British Isles. BSBI Handbook no. 1, edition 3. London: Botanical Society of the British Isles.

Jones, M.L.M., Wallace, H.L., Norris, D., Brittain, S.A., Haria, S., Jones, R.E., Rhind, P.M., Reynolds, B.R. \& Emmett, B.A. 2004. Changes in vegetation and soil characteristics in coastal sand dunes along a gradient of atmospheric nitrogen deposition. Plant Biology, 6: 598-605.

Millington, J.A., Booth, C.A., Fullen, M.A., Trueman, I.C. \& Worsley, A.T. 2010.

Distinguishing dune environments based on topsoil characteristics: a case study on the Sefton Coast. In: Worsley, A.T., Lymbery, G., Holden V.J.C. \& Newton, M. eds. Seftor's dynamic coast. 116-130. Southport: Sefton Technical Services Department.

Natural England 2014. Survey and analysis of vegetation and hydrological change in English dune slack habitats. Peterborough: Natural England commissioned report NECR153.

Olff, H., Huisman, J. \& Van Tooren, B.F. 1993. Species dynamics and nutrient accumulation during early primary succession in coastal sand dunes. Journal of Ecology, 81: 693-709.

Pignotti, L. \& Mariotti, L.M. 2004. Micromorphology of Scirpus (Cyperaceae) and related genera in south-west Europe. Botanical Journal of the Linnean Society, 145:45-58.

Plassmann, K., Edwards-Jones, G. \& Jones, M.L.M. 2009. The effects of low levels of nitrogen deposition and grazing on dune grassland. Science of the Total Environment, 407: 1391-1404.

Potter, J.A. \& Hosie, C.A. 2001. Using behaviours to identify rabbit impacts on dune vegetation at Aberffraw, North Wales. In: Houston, J.A., Edmondson, S.E. \& Rooney, P.J. eds. Coastal dune management: shared experience of European conservation practice, 108-116. Liverpool: Liverpool University Press.

Radley, G.P. 1994. Sand dune vegetation survey of Great Britain; a national inventory. Part 1: England. Peterborough: Joint Nature Conservation Committee.

Ranwell, D.S. 1972. Ecology of salt marshes and sand dunes. London: Chapman \& Hall. Regional Biodiversity Steering Group 1999. A biodiversity audit of north west England. 2 vols. Bootle: Merseyside Environmental Advisory Service. 
Rodwell, J.S. ed. 1991-2000. British plant communities volumes 1-5. Cambridge: Cambridge University Press.

Smith, P.H. 2006. Changes in the floristic composition of sand-dune slacks over a twenty year period. Watsonia, 26: 41-49.

Smith, P.H. 2007. The Birkdale Green Beach - a sand-dune biodiversity hotspot. British Wildlife, 19: 11-16.

Smith, P.H. 2009a. Distribution, status and ecology of Blysmus compressus (L.) Panz. ex Link on the Sefton Coast sand-dunes, Merseyside. Watsonia, 27: 339-353.

Smith, P.H. 2009b. The sands of time revisited. An introduction to the sand-dunes of the Sefton Coast. Stroud, Gloucestershire: Amberley publishing.

Smith, P.H. 2014. Juncus subnodulosus (Blunt-flowered Rush) in the Sefton Coast sanddunes, Merseyside (v.c.59, South Lancashire). BSBI NewS, 125: 12-20.

Smith, P.H. 2015. A revision of the inventory of vascular plants for the Sefton Coast, north Merseyside (v.c.59, South Lancashire), with particular reference to the 2014 Red List for England. BSBI News, 129: 36-40.

Smith, P.H. 2017a. The natural history of a sand-dune blowout. British Wildlife, 28: 329334

Smith, P.H. 2017b. Occurrence and ecology of Carex oederi (Small-fruited Yellowsedge) on the Sefton Coast, Merseyside (v.c.59, South Lancashire). BSBI News, 135: 22-28.

Stace, C.A. 2010. New flora of the British Isles. $3^{\text {rd }}$ ed. Cambridge: Cambridge University Press.

Stroh, P.A., Leach, S.J., August, T.A., Walker, K.J., Pearman, D.A., Rumsey, F.J., Harrower, C.A., Fay, M.F., Martin, J.P., Pankhurst, T., Preston, C.D. \& Taylor, I. 2014. A vascular plant red list for England. Bristol: Botanical Society of Britain \& Ireland.

Stroh, P.A. \& Walker, K.T. 2015. Blysmus compressus (L.) Panz. Ex Link. Flat-sedge. Species account. Botanical Society of Britain \& Ireland.

Walker, K.J., Stroh, P.A. \& Ellis, R.W. 2017. Threatened plants in Britain and Ireland. Bristol: Botanical Society of Britain \& Ireland.

Copyright retained by author(s). Published by BSBI under the terms of the Creative Commons Attribution 4.0 International Public License.

ISSN: $2632-4970$

https://doi.org/10.33928/bib.2019.01.070 